\title{
PENGARUH CELEBRITY ENDORSEMENT DAN BRAND IMAGE TERHADAP PURCHASE INTENTION LIPSTIK SARIAYU
}

\author{
Laveinia Septa Dwi Utami \\ Ponirin \\ Program Studi Manajemen, Fakultas Ekonomi, Universitas Tadulako \\ Email: Echaalaveinia@gmail.com; Ppaidjan@gmail.com
}

\begin{abstract}
The purpose of this study is to know the influence of celebrity endorsement and brand image on the purchase intention of Sari Ayu Lipstick products in Palu City. The number of samples in this study were 67 people. Sampling using purposive sampling technique. The analytical method used in this study is Partial Least Square/PLS with the help of the SmartPLS statistical program. The results showed that there was an influence of attractiveness, trustworthiness and expertise on brand image of Sari Ayu Lipstik products in Palu City, and there is an effect of the brand image on the purchase intention of Sari Ayu Lipstick products in Palu City.
\end{abstract}

Keywords: Endorsement, Brand Image, Purchase Intention.

\begin{abstract}
Abstrak
Tujuan penelitian ini adalah diketahuinya pengaruh celebrity endorsement dan brand image terhadap purchase intention produk Lipstik Sari Ayu di Kota Palu. Jumlah sampel dalam penelitian ini sebanyak 67 orang. Pengambilan sampel menggunakan teknik purposive sampling. Metode analisis yang digunakan dalam penelitian ini adalah Partial Least Square/PLS dengan bantuan program statistik SmartPLS. Hasil penelitian menunjukkan terdapat pengaruh attractiveness, trustworthiness dan expertise terhadap brand image produk Lipstik Sari Ayu di Kota Palu, serta terdapat pengaruh brand image terhadap purchase intention produk Lipstik Sari Ayu di Kota Palu.
\end{abstract}

Kata Kunci: Endorsement, Brand Image, Purchase Intention.

\section{PENDAHULUAN}

Kebutuhan untuk cantik dan tampil mempesona merupakan kebutuhan dasar bagi wanita yang melahirkan berbagai produk kosmetik. Pada saat ini, kosmetik menjadi sarana bagi wanita untuk memperjelas identitas dirinya kepada lingkungan sekitar. Mengangkat kosmetik merek lokal merupakan suatu langkah yang efektif guna mengenalkan produk buatan Indonesia ke pasar dalam negeri bahkan pasar global (Simamora, 2014).

Berdasarkan data Kemetrian Perindustrian, perkembangan industri kosmetik di Kota Palu saat ini tergolong sangat pesat. Hal ini dilihat dari data peningkatan penjualan kosmetik di Kota Palu tahun 2016 sebesar 36,18\%. Angka ini mengalami peningkatan jika dibanding tahun 2015 hanya sebesar 29,76\% (Kementerian Perindustrian RI, 2016). Ada berbagai kosmetik merek lokal yang pada saat ini sedang diminati konsumen di Kota Palu. Beberapa merek lokal tersebut yaitu Sari Ayu, Wardah, Emina, Dissy, Viva dan Mineral Botanica.

Petumbuhan jumlah penduduk wanita menghasilkan peningkatan permintaan akan produk kosmetik, sehingga mendorong peningkatan jumlah produsen yang masuk ke industri ini. Persaingan dalam industri kosmetik pun semakin ketat, yang menuntut produsen mengembangkan strategi-strategi pemasaran baru untuk menarik minat para konsumen dan mempertahankan konsumennya. Selain kualitas produk, promosi merupakan komponen penting lainnya dalam menarik minat konsumen yang akan meningkatkan penjualan dan pangsa pasar perusahaan.

Promosi memiliki bebarapa unsur yang dapat digunakan untuk mengkomunikasikan prooduk ke masyarakat, salah satunya yang paling efektif adalah iklan. Perusahaan harus mampu menghasilkan 
Vol. 6, No.3, September 2020, 186-194

iklan yang komunikatif, persuasif dan tentu saja menarik minat masyarakat. Bukan saja untuk melihat iklannya, tetapi juga tersti mulasi untuk melakukan pembelian.

Strategi komunikasi dengan menggunakan dukungan selebriti dalam mempromosikan suatu produk, nantinya akan berdampak juga pada brand image produk itu sendiri (Sabunwala, 2013). Celebrity endorser adalah orang yang sebagian besar dikenal oleh masyarakat luas dan memanfaatkan identifikasi tersebut untuk mendukung produk dalam iklan (Roy et al., 2013). Shafiq et al., (2011) menyatakan bahwa celebrity endorser merupakan sosok orang yang menarik, mampu mengiklankan produk dan memiliki kredibilitas yang baik, sehingga dapat menumbuhkan minat beli pada orang yang melihat iklan dan untuk membeli produk yang diiklankan. Pradhan et al., (2014) menyatakan bahwa dukungan celebrity endorser membantu konsumen untuk lebih berhubungan dengan selebriti dan dapat membantu dalam mengembangkan sikap positif terhadap merek untuk meningkatkan minat beli konsumen. Bagi perusahaan, celebrity endorser mempunyai peran yang sangat penting dalam mengiklankan suatu produk yang dapat meningkatkan dan menurunkan nilai dari suatu produk yang dipasarkan dan minat beli konsumen dapat meningkat apabila konsumen mendapatkan manfaat lebih dari apa yang konsumen bayar untuk sebuah produk (Hansudoh, 2012). Brand image yang baik akan menimbulkan nilai-nilai emosional konsumen, oleh sebab itu perusahaan perlu untuk meningkatkan brand image mereka karena nilai emosional ini akan memicu terjadinya persepsi yang positif akan suatu produk yang akan menimbulkan minat beli (Weli dan Rahyuda, 2016).

Selebriti tidak lain adalah seorang individu memiliki ketenaran sehingga sangat dikenal oleh masyarakat. Karena itulah yang dimanfaatkan oleh perusahaan untuk mempromosikan produk perusahaan dalam bentuk iklan atau kegiatan lainnya. Ketenaran seorang selebriti banyak dimanfaatkan oleh perusahaan, sehingga di dunia ini diperkirakan dari setiap enam iklan, satu di antaranya pasti menggunakan figur selebriti (Young dan Pinsky, 2011).

Ketika perusahaan memililih selebriti untuk mewakili produknya, sebaiknya mempertimbangkan beberapa hal antara lain tingkat ketenaran selebriti, memiliki pengaruh positif yang tinggi, dan memiliki kesesuaian yang tinggi dengan produk. Hal tersebut sangat penting mengingat selebriti tesebut menjadi personifikasi produk perusahaan yang menentukan kredibilitas produk di mata masyarakat (Kotler dan Keller, 2009).

Lebih lanjut, sebagai personifikasi produk maka selebriti juga menjadi cermin untuk mewakili segmen pasar yang dibidik. Keterwakilan konsumen dari sosok selebriti tersebut akan mendukung pesan iklan yang disampaikan sehingga pesan tersebut menetap di benak konsumen (Royan, 2013) dan tentu saja menghasilkan minat maupun niat untuk melakukan pembelian (Prisgunanto, 2014).

Berdasarkan penelitian-penelitian sebelumnya, salah satunya adalah hasil penelitian Ohanian (2008) yang menyatakan bahwa terdapat dua faktor penting yang mengarah pada minat konsumen yaitu credibility (kredibel) dan attractiveness (daya tarik) yang harus dimiliki oleh seorang selebriti. Masyarakat penggemar memandang seorang selebriti sebagai individu memiliki keunggulan,atraktif, dimana kata-kata kata-kata yang mereka ucapkan mampu memengaruhi seseorang terpusat pada mereka (Royan, 2013). Lebih lanjut Royan (2013) menyatakan bahwa selebritis seharusnya mampu memberikan dampak positif, yang memnghasilkan ikatan yang kuat antara image dan kualitas selebriti dengan produk (Royan, 2013).

Endorser dari produk lipstik Sari Ayu yaitu selebgram yang bernama Nanda Arsinta melalui akun Instagramnya. Endorser dari produk lipstik Sari Ayu di Facebook yaitu Pevita Pearce dan di Youtube yaitu Suhay Salim.

Daya tarik merupakan salah satu dimensi yang penting bagi produk yang diwakilinya karena akan menghasilkan image bagi produk tersebut. Penelitian mengungkapkan kecenderungan pengaruh positif daya tarik selebritis terhadap minat beli konsumen (Khan et al, 2016). Artinya bahwa tinggi rendahnya minat pembelian ditentukan oleh tinggi rendahnya daya tarik selebriti. 
Kepercayaan (trustwhortiness) dapat didefinisikan yaitu endorser tersebut dianggap dipercaya, jujur dan dapat diandalkan. Efeketivitas pembawa pesan atau selebritis ditentukan oleh karakteristik kunci ini. Kepercayaan yang dimiliki endorser juga mempunyai peran sangat penting dalam mempengaruhi niat pembelian (Khan et al, 2016).

Sebagai Endorser, selebriti merupakan seseorang yang mewakili produk yang membawa pesan sehingga mereka menjadi direct source (sumber langsung) bagi produk yang diwakilinya. Mereka juga pemeraga produk maupun jasa yang diwakilinya. Karenanya selebriti harus memiliki keahlian yang relevan dengan merek produk yang mereka iklankan (Kasali, 2012).

Pengaruh langsung antara citra merek dengan minat beli dikemukakan oleh Aaker (2007), semakin baik pandangan konsumen atas citra merek suatu produk akan menentukan setinggi apa minat beli konsumen dari suatu produk atau jasa. Rangkuti (2008) juga mengemukakan hal yang sama dimana semakin baik konsumen mempersepsikan produk atau merek, maka minat untuk membeli mereka akan semakin kuat. Dapat disimpulkan bawa selebriti memiliki peran yang penting dalam membentuk citra suatu merek atau produk. Selanjutnya citra mereka menentukan besar kecilnya minat beli konsumen atau calon konsumen.

Alasan peneliti tidak memilih variabel respect dan similarity karena pada penelitian yang dilakukan oleh Ohanian (2008) dikumpulkan beberapa literatur terdahulu dan mengusulkan tiga dimensi yang mempengaruhi kredibilitas sebagai endorser yaitu attractiveness, trustworthiness dan expertise. Selain itu, mengingat waktu penelitian yang akan relatif lama jika mengambil lebih dari tiga variabel eksogen, maka dari itu peneliti hanya memfokuskan mengambil tiga variabel eksogen saja, agar dapat menyesuaikan dengan jangka waktu penelitian yang telah direncanakan.

\section{KAJIAN LITERATUR DAN PENGEMBANGAN HIPOTESIS}

Seftian (2018) dalam penelitiannya menemukan hasil bahwa variabel celebrity endorsement berpengaruh secara positif terhadap purchase intention, celebrity endorsement berpengaruh secara positif terhadap brand image, brand image berpengaruh secara positif terhadap purchase intention dan celebrity endorsement berpengaruh secara positif terhadap purchase intention melalui brand image.

Celebrity endorsement merupakan salah satu dari banyak metode promosi yang menjadi pilihan utama di dunia. Keberhasilan mencitrakan produk di benak konsumen ditentukan oleh ketepatan perusahaan dalam memilih celebrity endorser. Royan (2013) selanjutnya memberikan syarat untuk keberhasilan celebrity yaitu harus memiliki attitude yang menyenangkan. Selain itu endorser juga harus merupakan orang yang dapat dipercaya (Royan, 2013).

Menurut Kotler dan Keller (2009) merek merupakan istilah, tanda, lambang atau desain atau kombinasinya yang dimaksudkan untuk mengidentifikasikan barang atau jasa dari salah satu penjual atau kelompok penjual dan mendiferensikan mereka dari para pesaing maka merek adalah produk atau jasa yang dimensinya mendiferensikan merek dengan beberapa cara, definisi merek merupakan hal yang sangat penting, baik bagi konsumen maupun produsen, dari sisi konsumen, merek mempermudah pembelian. Bila tidak ada merek, konsumen harus mengevaluasi semua produk yang tidak memiliki merek setiap kali mereka akan melakukan pembelian. Mereka juga membantu meyakinkan konsumen bahwa mereka akan mendapatkan kualitas yang konsisten ketika mereka membeli produk tersebut, dari sisi produsen, merek dapat dipromosikan. Merek dapat dengan mudah diketahui ketika diperhatikan atau ditempatkan dalam suatu display.

Purchase intention atau minat beli adalah sesuatu yang berhubungan dengan rencana konsumen untuk membeli produk tertentu, serta berapa banyak unit produk yang dibutuhkan pada periode tertentu (Durianto, 2009). Purchase intention adalah sesuatu yang timbul setelah menerima rangsangan dari produk yang dilihatnya, lalu muncul keinginan untuk membeli dan memilikinya (Kotler dan Amstrong, 2012). 
Vol. 6, No.3, September 2020, 186-194

Attractiveness (daya tarik) Dimensi (attractiveness) merupakan tingkatan dimana sebuah obyek dinilai melalui perilaku yang simpatik, mempunyai ambisi, kecerdasan dan karakteristik kepribadian lainnya. Terdapat lima variabel dalam dimensi attractiveness, yaitu: attractive, classy, beautiful, sexy, dan elegant (Ohanian, 2008).

Ohanian (2008) mengemukakan bahwa tingkat kepercayaan (trustworthiness) mengacu pada kepercayaan konsumen kepada sumber untuk memberikan informasi dengan cara yang objektif dan jujur. Selain itu, ia juga mengatakan bahwa sebuah pesan iklan dapat mengubah sikap audient, jika mereka menganggap bahwa pembawa pesan dapat dipercaya.

Ohanian (2008) menemukan bahwa keahlian (expertise) seorang pendukung mempengaruhi tingkat kepercayaan konsumen terhadap produk, sehingga hal ini menjadi faktor penting dalam meningkatkan efektifitas proses penyampaian pesan pemasaran dari produsen (perusahaan) kepada konsumen melalui pendukung sebagai mediatornya.

\section{METODE PENELITIAN}

Jenis penelitian yang digunakan adalah kuantitatif berupa survey. Penelitian mengambil tempat di Kota Palu, dalam kurun waktu bulan Mei sampai dengan Juni tahun 2019. Populasi dalam penelitian ini adalah konsumen wanita pengguna produk Sari Ayu yang berumur minimal 17 tahun yang berdomisili di Kota Palu. Sedangkan jumlah populasi tidak diketahui. Pengambilan sampel menggunakan teknik non-probability sampling, yaitu purposive sampling atau teknik dimana sampel dipilih atas pertimbangan syarat tertentu (Sugiyono, 2010). Kriteria inklusi yaitu bersedia menjadi responden, perempuan, membeli produk Lipstik Sari Ayu. Kriteria eksklusi yaitu mempunyai gangguan pendengaran, tergesa-gesa.

\section{Ukuran Sampel}

Untuk parameter populasi yang tidak diketahui jumlahnya, maka ukuran sampel diambil menggunakan formula Estimasi Proporsi sebagai berikut (Sugiyono, 2010):

$$
n=\frac{Z_{1-\alpha / 2}^{2} P(1-P)}{d^{2}}
$$

Keterangan:

$\mathrm{n}=$ Besar sampel

$\mathrm{d}=$ besar penyimpangan (absolut) yang bisa diterima $=0,12$

$\mathrm{Z}_{1-\alpha / 2}^{2}=$ nilai sebaran normal baku yang besarnya tergantung $\alpha(1,96)$

$\mathrm{P}=$ proporsi pada populasi $50 \%=\mathrm{u} 0,5$

Sampel berjumlah 67 sampel. Penelitian ini menggunakan analisis deskriptif dan analisis regresi partial (Partial Least Square/PLS).

\section{HASIL DAN PEMBAHASAN}

\section{HASIL}

\section{Koefisien Determinasi $\left(\mathbf{R}^{2}\right)$}

Nilai $\mathrm{R}^{2}$ untuk variabel brand image adalah 0,889 . Perolehan nilai tersebut menjelaskan bahwa persentase besarnya brand image dapat dijelaskan oleh attractiveness, trustworthinass, dan expertise sebesar $88,9 \%$. Kemudian untuk nilai $\mathrm{R}^{2}$ yang diperoleh variabel purchase intention sebesar 0,918 . Nilai tersebut menjelaskan bahwa purchase intention dapat dijelaskan oleh brand image sebesar $91,8 \%$. Nilai $\mathrm{R}^{2}$ diperoleh lebih dari 0,67 , sehingga hal demikian dapat disimpulkan bahwa model adalah kuat. 
nilai $\mathrm{Q}^{2}$ untuk variabel brand image sebesar 0,673 dan purchase intention sebesar 0,706. Perolehan nilai tersebut adalah sama dengan 0 , sehingga model ini mempunyai predictive relevance yang akurat terhadap variabel.

\section{Effect Size $\left(\mathbf{f}^{2}\right)$}

nilai $\mathrm{f}^{2}$ untuk pengaruh attractivness terhadap brand image adalah $0,334(>0,15)$, hal ini menunjukkan bahwa pengaruh attractivness terhadap brand image adalah sedang. Nilai $\mathrm{f}^{2}$ untuk pengaruh trustworthiness terhadap brand image adalah 0,090 (>0,02), hal ini menunjukkan bahwa pengaruh trustworthiness terhadap brand image adalah kecil. Nilai $\mathrm{f}^{2}$ untuk pengaruh expertise terhadap brand image adalah 0,410 (>0,35), hal ini menunjukkan bahwa pengaruh expertise terhadap brand image adalah besar. Nilai $\mathrm{f}^{2}$ untuk pengaruh brand image terhadap purchase intention adalah 11,240 (> 0,35), hal ini menunjukkan bahwa pengaruh brand image terhadap purchase intention adalah besar.

\section{Path Coefficient}

Path coefficient digunakan untuk menunjukkan seberapa kuat efek atau pengaruh variabel eksogen terhadap variabel endogen. Nilai path coefficient berkisar antara -1 hingga +1 . Semakin mendekati nilai +1 maka pengaruh kedua variabel semakin kuat, akan tetapi jika semakin mendekati -1 maka pengaruh kedua variabel tersebut bersifat negatif. Berdasarkan Tabel 4 di atas bahwa nilai path coefficient terbesar ditujukkan dengan pengaruh brand image terhadap purchase intention sebesar 11,240 , nilai ini lebih dari nilai +1 sehingga dapat disimpulkan bahwa pengaruh brand image terhadap purchase intention sangat kuat. Pengaruh terbesar kedua adalah expertise terhadap brand image dengan nilai path coefficient sebesar 0,410 , nilai ini berada di bawah +1 dan di atas -1 sehingga dapat disimpulkan bahwa pengaruh expertise terhadap brand image adalah sedang. Pengaruh terbesar ketiga adalah attractivness terhadap brand image dengan nilai path coefficient sebesar 0,334 , nilai ini berada di bawa +1 dan di atas -1 sehingga disimpulkan bahwa pengaruh attractivness terhadap brand image adalah sedang. Kemudian pengaruh terbesar keempat adalah trustworthiness terhadap brand image dengan nilai path coefficient sebesar 0,090 , nilai ini berada di bawah nilai +1 dan di atas nilai -1 sehingga dapat disimpulkan bahwa pengaruh trustworthiness terhadap brand image adalah sedang.

\section{PEMBAHASAN}

\section{Pengaruh Attractiveness terhadap Brand Image}

Pada penelitian ini attractiveness diartikan sebagai daya tarik model iklan produk Lipstik Sari Ayu dalam meningkatkan minat beli konsumen. Daya tarik/attractiveness tersebut diukur dengan 3 indikator, yaitu seksi, elegant, dan beauty. Hasil penelitian yang dilakukan pada konsumen produk Lipstik Sari Ayu di Kota Palu pada attractiveness, dimana seksi merupakan indikator yang dominan dipilih oleh responden karena bintang iklan produk Lipstik Sari Ayu memiliki bibir yang seksi, hal ini dapat dilihat pada beberapa endorser dari Lipstik Sari Ayu salah satunya seperti Pevita Pearce, bintang iklan yang mempunyai daya tarik akan meningkatkan citra merek sehingga hal ini yang menjadi alasan konsumen dalam membeli Produk Lipstik Sari Ayu.

Selain itu elegant merupakan indikator yang dapat meningkatkan citra merek Lipstik Sari Ayu, bintang iklan produk Lipstik Sari Ayu terlihat anggun, akan mempengaruhi citra merek di mata konsumen sehingga dapat meningkatkan minat konsumen dalam membeli produk Liptik Sari Ayu.Berdasarkan hasil olah data diperoleh hasil terdapat pengaruh antara attractiveness terhadap brand image di Kota Palu. 
Vol. 6, No.3, September 2020, 186-194

Hal ini menunjukan bahwa salah satu strategi yang digunakan oleh peruhaan PT. Sari Ayu Indonesia dalam menawarkan produk lipstiknya dengan cara menarik minat beli konsumen melalui endorser. Perusahaan mencoba mencocokan image produk dengan kepribadian ataupun fisik dari endorser yang dipilih. Penggunaan endorser yang mempunyai daya tarik diharapkan dapat meningkatkan brand image, sehingga dapat muncul pemikiran atau citra tertentu di mata konsumen terhadap produk Lipstik Sari Ayu yang berdampak pada tingginya minat beli. Semakin tinggi daya tarik endorser, maka semakin tinggi pula citra merek dari produk Lipstik Sari Ayu, akan tetapi jika semakin rendah daya tarik endorser maka semakin rendah pula citra merek produk Lipstik Sari Ayu.

Penelitian ini sejalan dengan hasil penelitian yang dilakukan oleh Kurniawan dan Kunto (2014) bahwa terdapat pengaruh attractiveness terhadap brand image. Hasil ini menyimpulkan bahwa semakin meningkat attractiveness maka semakin meningkat pula brand image Bedak Marcks Venus.

\section{Pengaruh Trustworthiness Terhadap Brand Image}

Pada penelitian ini trustworthiness diartikan sebagai kepercayaan dari seorang endorser dalam meyakinkan konsumen untuk membeli Lipstik Sari Ayu. Kepercayaan/trustworthiness tersebut diukur dengan 3 indikator, yaitu jujur, integritas dan dapat dipercaya.

Hasil penelitian yang dilakukan pada konsumen produk Lipstik Sari Ayu di Kota Palu pada trustworthiness, dimana "dapat dipercaya" merupakan indikator yang dominan oleh responden karena bintang iklan Lipstik Sari Ayu dalam menyampaikan pesan di iklan dapat dipercaya oleh konsumen.

Selain itu "integritas" merupakan indikator yang dapat meningkatkan citra merek Lipstik Sari Ayu, dimana jika bintang iklan konsisten dalam menyampaikan pesan pada iklan maka hal demikian dapat meningkatkan citra merek produk Lipstik Sari Ayu yang bisa berdampak minat beli dari konsumen.

Berdasarkan hasil olah data diperoleh hasil terdapat pengaruh antara trustworthiness terhadap brand image di Kota Palu. Hal ini menunjukkan bahwa semakin tinggi kepercayaan yang diberikan endorser dalam meyakinkan konsumen maka semakin meningkat pula brand image dari produk Lipstik Sari Ayu, akan tetapi jika rendah kepercayaan tersebut maka rendah pula brand image dari produk Lipstik Sari Ayu. Citra yang baik merupakan salah satu cara yang efektif dalam menjaring konsumen, citra yang baik dapat dilihat pula dari endorser dalam meningkatkan kepercayaan konsumen karena sebagian besar konsumen akan memilih suatu produk yang memiliki brand image yang positif.

Peneltian ini sejalan dengan hasil penelitian yang dilakukan oleh Cholifah et al., (2016) bahwa terdapat pengaruh yang signifikan antara trustworthiness terhadap brand image. Penelitian ini menunjukkan bahwa selebriti dalam iklan Wardah telah mendaptkan kepercayaan untuk menyampaikan pesan iklan pada konsumen.

\section{Pengaruh Expertise Terhadap Brand Image}

Pada penelitian ini expertise diartikan sebagai keahlian/keterampilan yang dimiliki oleh seorang endorser sehingga menarik minat konsumen untuk membeli produk Lipstik Sari Ayu. Keahlian/expertise tersebut diukur dengan 3 indikator, yaitu pengetahuan, pengalaman dan persuasif.

Hasil penelitian yang dilakukan pada konsumen produk Lisptik Sari Ayu di Kota Palu pada expertise, dimana "pengalaman" merupakan indikator yang domain oleh responden karena menurut konsumen bahwa endorser produk Lipstik Sari Ayu terampil dalam menyampaikan iklan Lipstik Sari Ayu.

Selain itu "pengetahuan" merupakan indikator yang dapat meningkatkan citra merek Lipstik Sari Ayu, karena endorser iklan Lipstik Sari Ayu yang mempunyai penegatahuan luas dalam menyampaikan pesan dalam iklan dapat meningkatkan citra merek serta meningkatkan minat beli konsumen terhadap Lipstik Sari Ayu. 
Vol. 6, No 3, September 2020, 186-194

Berdasarkan hasil olah data bahwa terdapat pengaruh antara expertise terhadap brand image di Kota Palu. Hal ini menunjukkan bahwa semakin tinggi keahlian endorser dalam menarik konsumen untuk membeli Lipstik Sari Ayu, maka semakin tinggi pula citra merek yang dapat meningkatkan minat beli konsumen pada produk Lipstik Sari Ayu. Akan tetapi jika semakin rendah keahlian endorser dalam menarik konsumen untuk membeli Lisptik Sari Ayu, maka semakin rendah pula citra merek Lipstik Sari Ayu dan hal ini akan berdampak pada minat beli konsumen. Endorser yang memiliki keahlian dalam memberikan pesan iklan pada konsumen akan lebih mudah diingat oleh konsumen dan memudahkan pelaku bisnis untuk menarik perhatian konsumen, untuk membentuk image dan kepercayaan konsumen, sehingga meningkatkan daya beli konsumen.

Penelitian ini sejalan dengan hasil penelitian yang dilakukan oleh Cholifah et al., (2016) bahwa terdapat pengaruh yang signifikan antara expertise terhadap brand image. Penelitian ini menunjukkan bahwa pengetahuan, pengalaman serta keahlian endorser Wardah dalam membawa iklan mampu meyakinkan konsumen serta mampu memberikan pengaruh terhadap brand image kosmetik Wardah.

\section{Pengaruh Brand Image Terhadap Purchase Intention}

Pada penelitian ini brand image diartikan sebagai citra merek yang dimiliki oleh produk Lipstik Sari Ayu dalam menarik minat konsumen untuk membeli produk Lispstik Sari Ayu. Citra merek/brand image tersebut diukur dengan 3 indikator yaitu tingkat atribut fisik, tingkat implikasi fungsional dan implikasi psiko sosial.

Hasil penelitian yang dilakukan pada konsumen produk Lisptik Sari Ayu di Kota Palu pada brand image, dimana "impikasi psiko sosial" merupakan indikator yang dominan oleh responden karena saat menggunakan produk Lipstik Sari Ayu, konsumen mempunyai kepuasan tersendiri.

Selain itu "tingkat atribut fisik" merupakan indikator yang dapat meningkatkan minat beli dari konsumen terhadap produk Lipstik Sari Ayu, karena logo atau lambang merek produk Sari Ayu mudah diingat sehingga hal ini dapat meningkatkan minat beli konsumen pada Lipstik Sari Ayu.

Berdasarkan hasil penelitian bahwa terdapat hubungan pengaruh brand image terhadap purchase intention di Kota Palu. Hal ini menujukkan bahwa semakin tinggi brand image dari produk Lipstik Sari Ayu maka semakin meningkat pula minat beli konsumen. Akan tetapi semakin rendah brand image dari produk Lipstik Sari Ayu maka semakin rendah pula minat beli konsumen. Salah satu komponen keputusan pembelian adalah keputusan tentang merek, perusahaan harus mengetahui bagaimana konsumen harus memilih sebuah merek dalam melakukan pembelian dan kebanyakan konsumen memilih merek yang sudah dikenal. Ketika citra dari sebuah merek dipandang positif oleh konsumen maka merek tersebut akan selalu diingat dan disukai dibenak konsumen tersebut.

Hasil ini diperkuat dengan penelitian yang dilakukan oleh Sibarani dan Hananto (2015) yang menyatakan bahwa ada pengaruh yang signifikan dari brand image terhadap purchase intention. Merek yang terkenal dan memiliki kualitas yang baik akan memenangkan pasar.

\section{KESIMPULAN DAN SARAN}

\section{KESIMPULAN}

Berdasarkan hasil dan pembahasan dalam penelitian ini, maka dapat disimpulkan bahwa:

a. Ada pengaruh daya tarik selebriti terhadap citra merek produk Lipstik Sari Ayu di Kota Palu

b. Ada pengaruh kepercayaan selebriti terhadap citra merek produk Lipstik Sari Ayu di Kota Palu

c. Ada pengaruh keahlian selebriti terhadap citra merek produk Lipstik Sari Ayu di Kota Palu.

d. Ada pengaruh citra merek terhadap minat beli produk Lipstik Sari Ayu di Kota Palu.

\section{SARAN}

Berdasarkan uraian hasil penelitian dan kesimpulan, maka ada beberapa hal yang perlu direkomendasikan kepada pihak-pihak yang terkait dalam penelitian ini yaitu: 
Vol. 6, No.3, September 2020, 186-194

a. Perusahaan disarankan untuk tetap memperhatikan tingkat kepercayaan konsumen terhadap selebriti dalam menyampaikan iklan Lipstik Sari Ayu serta lebih menggali dan meningkatkan keahlian endorser untuk menarik minat beli konsumen. Untuk menambah kepercayaan konsumen misalnya dengan meningkatkan penggunaan selebriti yang memiliki kredibilitas dan popularitas yang tinggi serta disukai oleh banyak konsumen, sehingga nantinya akan membentuk citra yang baik di mata konsumen terhadap produk dan melakukan keputusan pembelian pada produk Lipstik Sari Ayu.

b. Peneliti selanjutnya diharapkan menggunakan indikator lain di luar indikator-indikator celebrity endorsment, brand image dan purchase intention yang sudah ada dalam penelitian ini, sehingga bisa mengembangkan butir-butir lain yang bisa mewakili celebrity endorsment, brand image dan purchase intention.

\section{REFERENSI}

Aaker, D. A. (2007). Managing Brand Equity. New York: Free Press.

Cholifah, N., Suharyono., dan Hidayat, K. (2016). Pengaruh Celebrity Endorser Terhadap Brand Image. Jurnal Administrasi Bisnis, Vol 36, 1 Juli 2016, 170.

Durianto, D. (2009). Brand Equity Ten, Strategi Memimpin Pasar. Jakarta: PT Gramedia Pustaka Utama.

Hansudoh, S. A. (2012). Pengaruh Celebrity Endorsement Terhadap Purchase Intention Melalui Perceived Value Pada Produk Top Coffe di Surabaya. E-Journal Universitas Katolik Widya Mandala Surabaya, 1 (05), h: 1-7.

Kasali, R. (2012). Manajemen Periklanan. Konsep-konsep dan Aplikasinya di Indonesia. Jakarta: PT Pustaka Utama Grafiti.

Kementerian Perindustrian RI. (2016). Pameran Produk Industri Kosmetik. Diperoleh dari http://www.kemenperin.go.id/artikel/6324/Kemenperin-Gelar-Pameran-Produk-Industrikosmetik.

Khan., Shaista, K., Rukhsar, A., dan Shoaib, M. (2016). Influence of Celebrity Endorsement on Consumer Purchase. IOSR Journal of Business and Management, Vol. 18, pp. 06-09.

Kotler, P., dan Amstrong, G. (2012). Prinsip-prinsip Pemasaran (Edisi Ketiga belas Jilid 1). Jakarta: Erlangga.

Kotler, P., dan Keller, K. L. (2009). Manajemen Pemasaran (Edisi Ketiga Belas). Jakarta: Erlangga.

Kurniawan, F. J., dan Kunto, Y. S. (2014). Analisa Pengaruh Vasibility, Credibility, Attraction dan Power Celebrity Endorser Terhadap Brand Image Bedak Marcks Venus. Jurnal Manajemen Pemasaran Petra, 2 (1), 1-8.

Ohanian, S. (2008). Pengaruh Celebrity Endorsement Terhadap Minat Pembelian Produk Kosmetik Online di Kota Medan, Skripsi, USU, Medan.

Pradhan, D., Israel, D., dan Dhruv, S. (2014). Celebrity Endorsement: How Celebrity-Brand-User Personality Congruence Affects Brand Attitude And Purchase Intention. Journal of Marketing Communications, 2(2): pp. 1-18.

Prisgunanto, I. (2014). Komunikasi Pemasaran: Strategi dan Taktik. Jakarta: Ghalia Indonesia.

Rangkuti, F. (2008). The Power of Brands. Jakarta: Gramedia Pustaka Utama. 
Vol. 6, No 3, September 2020, 186-194

Roy, S., Jain, V., dan Rana, P. (2013). The Moderating Role of Consumer Personality and Source Credibility in Celebrity Endorsements. Asia-Pacific Journal of Business Administration, 5(1), pp: $72-88$.

Royan, F. (2013). Marketing Celebrities. Jakarta: PT. Elex Media Komputindo.

Sabunwala, Z. (2013). Impact of Celebrity Brand Endorsements on Citra merekand Product Purchase -A Study for Pune Region of India. International Journal of Research in Business Management, 1(6), pp: 37-42.

Seftian, J. (2018). Pengaruh Celebrity Endorsement (Raisa Andriana) terhadap Purchase Intention dengan Brand Image Sebagai Variabel Intervening pada Produk Oppo Smartphone, Skripsi, Universitas Lampung, Bandar Lampung.

Shafiq, R., Raza, I., dan Rehman, M. Z. (2011). Analysis of The Factors Affecting Customers' Purchase Intention: The Mediating Role of Percieved Value. African Journal of Business Management, 5 (26), pp: 10577-10585.

Sibarani, M., dan Hananto, A. (2015). Analisis Pengaruh Store Image, Store Brand Price Image dan Store Brand Perceived Risk Sebagai Variabel Mediasi Terhadap Purchase Intention pada Produk Store Brand Ritel Watsons. Departemen Manajemen Fakultas Ekonomi Universitas Indonesia, Depok.

Simamora, H. (2014). Manajeman Pemasaran Internasional. Jakarta: Rineka cipta.

Sugiyono. (2010). Metode Penelitian Pendidikan Pendekatan Kuantitatif, Kualitatif, dan R\&D. Bandung: Alfabeta.

Utari, D. Y., Rombe, E., dan Ponirin. (2018). Pengaruh Pengalaman Merek dan Citra Merek Menggunakan Lipstik Purbasari di Kota Palu. Jurnal Ilmu Manajemen Universitas Tadulako, Vol. 4, No. 3, 229-234.

Weli, I. M., dan Rahyuda, I. K. (2016). Peran Brand Image dalam Memediasi Country of Origin terhadap Purchase Intention. E-Jurnal Manajemen Universitas Udayana, Vol. 5, No. 3 , hal : 1690-1716.

Young, M. S., dan Pinsky, D. (2011). Narcissism and Celebrity. Journal of Research in Personality, 1-9. 